\title{
Effect of monensin in lactating dairy cow diets at 2 starch concentrations
}

\author{
M. S. Akins, ${ }^{\star 1}$ K. L. Perfield, $†$ H. B. Green, $†$ S. J. Bertics, $\neq$ and R. D. Shaver \\ *School of Agriculture, University of Wisconsin, Platteville 53818 \\ †Elanco Animal Health, Greenfield, IN 46140 \\ ‡Department of Dairy Science, University of Wisconsin, Madison 53706
}

\section{ABSTRACT}

The objective of this study was to determine the effects of monensin (M) supplementation on lactation performance of dairy cows fed diets of either reduced (RS) or normal (NS) starch concentrations as total mixed rations. One hundred twenty-eight Holstein and Holstein $\times$ Jersey cows $(90 \pm 33 \mathrm{~d}$ in milk) were stratified by breed and parity and randomly assigned to 16 pens of 8 cows each in a randomized controlled trial. Pens were then randomly assigned to 1 of 4 treatments in a $2 \times 2$ factorial arrangement of treatments. A 4 -wk covariate adjustment period preceded the treatment period, with all pens receiving NS supplemented with $18 \mathrm{~g}$ of monensin/t of dry matter (DM). Following the 4 -wk covariate adjustment period, cows were fed their assigned treatment diets of NS with M (18 $\mathrm{g}$ of monensin/t), NS with $0 \mathrm{~g}$ of monensin/t (C), RS with $\mathrm{M}$, or RS with $\mathrm{C}$ for 12 wk. Actual starch concentrations for the RS and NS diets were 20.4 and 26.9\% (DM basis), respectively. Mean dry matter intake (DMI; 27.0 $\mathrm{kg} / \mathrm{d}$ ) was unaffected by the treatments. Feeding $\mathrm{M}$ compared with C and NS compared with RS increased milk yield by 1.3 and $1.5 \mathrm{~kg} / \mathrm{d}$ per cow, respectively. Milk protein percentage and yield and lactose yield were increased and milk urea nitrogen was decreased for NS compared with RS. Feeding M increased actual and component-corrected milk feed efficiencies (componentcorrected milk yield/DMI) and lactose yield and tended to increase milk urea nitrogen compared with C. Milk protein percentage was decreased for $\mathrm{M}$ compared with $\mathrm{C}$, but milk fat percentage and yield, protein yield, and lactose percentage were unaffected by M. We observed a tendency for a starch $\times$ monensin interaction for milk feed efficiency (actual milk yield/DMI); M tended to increase efficiency more for NS than for RS. Starch and monensin had minimal effects on milk fatty acid composition and yields. Feeding RS decreased milk and protein yields, but component-corrected milk yields and feed efficiencies were similar for RS and NS. Monensin

Received March 5, 2013.

Accepted October 6, 2013.

${ }^{1}$ Corresponding author: akinsm@uwplatt.edu increased feed efficiency and lactation performance for both dietary starch concentrations.

Key words: dairy cow, feed efficiency, monensin, starch

\section{INTRODUCTION}

Kaiser and Shaver (2006) and Bucholtz (2006) reported that starch concentrations in diets fed to highproducing dairy herds ranged from 25 to 30\% (DM basis). Increased corn prices have heightened interest in feeding reduced-starch diets. Results from short-term dairy cattle feeding trials suggest that reduced-starch diets formulated by partially replacing corn grain with high-fiber, low-starch byproduct feedstuffs may be economically feasible (Shaver, 2010). Longer term studies are needed, however, to better understand the effects of feeding reduced-starch diets on lactation performance.

In a 12 -wk trial with high-producing ( $50 \mathrm{~kg}$ of milk/d) dairy cows, Gencoglu et al. (2010) reported similar milk yield, greater DMI and FCM yield, and a trend for reduced actual-milk (not corrected for components) feed efficiency for cows fed a reduced-starch (RS; $21 \%$ starch, DM basis) diet formulated by partially substituting soy hulls for dry ground shelled corn (DGSC) contained in the normal-starch (NS; $27 \%$ starch, DM basis) diet. Even though feed cost per kilogram of DM was reduced for the RS diet, feed cost per cow per day was greater for RS because DMI was $9 \%$ greater and actual-milk feed efficiency was $7 \%$ lower for RS compared with NS. In a subsequent trial, Ferraretto et al. (2011) reported that using a wheat middlings and whole cottonseed mixture rather than soy hulls to partially replace DGSC in the RS diet increased DMI by $8 \%$ and reduced actual-milk feed efficiency by $10 \%$ for cows fed RS compared with NS.

Firkins (1997) suggested that greater digestibility and passage rate for nonforage or byproduct NDF can allow for increased NDF intake and fill, thereby increasing the threshold for limitation of DMI by dietary NDF content (Mertens, 1987). Greater DMI for RS versus NS diets (Gencoglu et al., 2010; Ferraretto et al., 2011) may be related to reduced ruminal propionate concen- 
tration (Allen, 1997), leading to increased meal size and consequently greater DMI (Allen et al., 2009).

Monensin (M) is an ionophore that alters rumen microbial populations and proportion of ruminal VFA. Monensin has been shown to increase ruminal propionate, decrease DMI, and increase milk production efficiency in dairy cows (Ipharraguerre and Clark, 2003b; Duffield et al., 2008). Monensin has also been associated with decreased milk fat percentage and yield (Broderick, 2004; AlZahal et al., 2008) and changes in milk FA proportions (He et al., 2012). These changes are caused by $\mathrm{M}$ inhibiting $\mathrm{FA}$ biohydrogenation by rumen microorganisms (Fellner et al., 1997) and increased flow of trans-C18:1 FA to the small intestine, which inhibits mammary gland FA synthesis (Bauman and Griinari, 2001). Changes in milk fat composition with $\mathrm{M}$ supplementation have been reported to be influenced by dietary factors, such as NDF and NFC concentrations, and delivery method of the diet (Duffield et al., 2003). Previous studies have investigated the effect of $\mathrm{M}$ on lactating cows fed diets differing in forage to concentrate ratio (Ramanzin et al., 1997); however, we have found no studies that evaluated the effect of both M supplementation and dietary starch concentrations in dairy cattle. Monensin was not fed in the RS versus NS studies of Gencoglu et al. (2010) and Ferraretto et al. (2011). The objectives of the current study were to evaluate possible interactions of monensin supplementation and dietary starch content on lactation performance and milk FA composition of lactating dairy cows. Our hypothesis was that monensin supplementation would reduce DMI and improve milk production efficiency more with RS than with NS diets. This response could expand the economic opportunities for feeding RS diets to high-producing dairy cows when economically advantageous.

\section{MATERIALS AND METHODS}

\section{Cows and Treatments}

The experimental protocol was approved by the Animal Care and Use Committee of the College of Agriculture and Life Sciences at the University of WisconsinMadison. One-hundred twenty-eight cows $(90 \pm 33$ DIM) were stratified by breed (Holstein and Holstein $x$ Jersey crossbred) and parity (primi- and multiparous), and randomly assigned to 16 pens of 8 cows each in a randomized controlled trial in the University of Wisconsin-Madison Emmons-Blaine Arlington freestall, milking parlor dairy facility. Each pen consisted of 3 primiparous Holstein, 3 multiparous Holstein, and 2 multiparous Holstein $\times$ Jersey crossbred cows. Pens were randomly assigned to 1 of 4 treatments with 4 pens per treatment in a $2 \times 2$ factorial arrangement of treatments with 2 dietary starch concentrations (S; $21 \%$ vs. $27 \%$ of DM for RS and NS, respectively) and 2 dietary concentrations of monensin (Rumensin, Elanco Animal Health, Greenfield, IN) supplementation [control $(\mathbf{C})$ and $\mathrm{M}$ at 0 and $18 \mathrm{~g} / \mathrm{t}$ of $\mathrm{DM}$, respectively] as main effects for a continuous lactation experiment. Randomization was done by randomly drawing paper slips numbered 1 to 16 to assign cows to pens and paper slips labeled with the treatment name to assign treatments to pens. The number of pens per treatment was determined using standard deviations of data from previous continuous lactation studies done in these pens and the difference between treatments to be detected. Using differences of $1 \mathrm{~kg}$ for DMI, $1.5 \mathrm{~kg}$ for milk yield, and 0.2 percentage units for milk fat content, an $\alpha$ error level of 0.05 , and a $\beta$ error level of 0.20 , the number of pens needed was 8 for the main effects of starch and monensin. Treatments were blinded to the milking staff but not to the study investigators, herd management staff, or feeding staff. The lack of treatment blinding was not anticipated to affect results in this study. The RS diet was formulated by partially replacing DGSC with pelleted soy hulls. All cows were receiving $11 \mathrm{~g}$ of monensin/t of DM before the start of the 4-wk covariate period. During the 4 -wk covariate period, all cows were fed the NS diet with $18 \mathrm{~g}$ of monensin/t of DM (NS-M) followed by a 12 -wk treatment period with cows fed their assigned treatment diets of NS-M, NS with $0 \mathrm{~g}$ of monensin/t of DM (NS-C), RS with $0 \mathrm{~g}$ of monensin/t of DM (RS-C), and RS with $18 \mathrm{~g}$ of monensin/t of DM (RS-M). Ingredient composition of the diets is provided in Table 1 and that of the grain mixes and treatment premixes is provided in Table 2 . On d 1 of the treatment period, pens assigned NS-C and RS-C were switched to $0 \mathrm{~g}$ of monensin/t of diet $\mathrm{DM}$, whereas the other pens continued to receive $18 \mathrm{~g}$ of monensin/t of diet DM. All cows were commingled for the first $2 \mathrm{wk}$ of the covariate period and then assigned to their respective 8 -cow pens for the second $2 \mathrm{wk}$ of the covariate period and the 12 -wk treatment period. All cows received bovine somatotropin (Posilac, Elanco Animal Health) every $14 \mathrm{~d}$ starting at 57 to 70 DIM, with all cows on bST by d 15 of the covariate period.

Diets were fed as TMR mixed and fed once daily. The M or C premixes (Vita Plus Corp., Madison, WI) were added to the TMR separately from the concentrate mixtures to provide an average intake of $227 \mathrm{~g} /$ cow per day. The pens were supplied with TMR to allow for $5 \%$ refusals, with daily DMI determined on a pen basis throughout the study. Control pens received their daily feed allotment first, followed by the monensin treatment pens. Daily pen refusals were recorded each morning before new feed delivery using feeding 
Table 1. Dietary ingredients and TMR nutrient composition ${ }^{1}$

\begin{tabular}{|c|c|c|c|c|}
\hline \multirow[b]{2}{*}{ Item } & \multicolumn{2}{|c|}{ Reduced starch } & \multicolumn{2}{|c|}{ Normal starch } \\
\hline & Control & Monensin & Control & Monensin \\
\hline \multicolumn{5}{|l|}{ Ingredient, $\%$ of DM } \\
\hline Corn silage & 25.0 & 25.0 & 25.0 & 25.0 \\
\hline Alfalfa silage & 25.0 & 25.0 & 25.0 & 25.0 \\
\hline Reduced starch mix ${ }^{2}$ & 49.1 & 49.1 & 0.0 & 0.0 \\
\hline Normal starch mix ${ }^{2}$ & 0.0 & 0.0 & 49.1 & 49.1 \\
\hline Control premix ${ }^{2}$ & 0.9 & 0.0 & 0.9 & 0.0 \\
\hline Monensin premix ${ }^{2}$ & 0.0 & 0.9 & 0.0 & 0.9 \\
\hline \multicolumn{5}{|l|}{ Nutrient } \\
\hline DM, \% as fed & $52.6 \pm 2.9$ & $52.7 \pm 2.1$ & $53.2 \pm 3.0$ & $52.4 \pm 2.1$ \\
\hline $\mathrm{CP}, \%$ of $\mathrm{DM}$ & $18.1 \pm 0.5$ & $18.0 \pm 0.6$ & $18.2 \pm 0.7$ & $18.3 \pm 0.6$ \\
\hline $\mathrm{NDF}, \%$ of $\mathrm{DM}$ & $34.7 \pm 1.0$ & $35.0 \pm 1.3$ & $28.3 \pm 0.8$ & $28.6 \pm 1.2$ \\
\hline Forage NDF, $\%$ of DM & $19.5 \pm 0.6$ & $19.5 \pm 0.6$ & $19.5 \pm 0.6$ & $19.5 \pm 0.6$ \\
\hline Ether extract, $\%$ of DM & $6.1 \pm 0.9$ & $5.7 \pm 0.4$ & $6.0 \pm 0.5$ & $5.8 \pm 0.5$ \\
\hline Ash, $\%$ of DM & $8.0 \pm 0.3$ & $8.0 \pm 0.1$ & $7.8 \pm 0.2$ & $7.8 \pm 0.1$ \\
\hline $\mathrm{NFC}^{3} \%$ of DM & $33.1 \pm 1.8$ & $33.3 \pm 1.5$ & $39.6 \pm 1.1$ & $39.5 \pm 1.7$ \\
\hline Starch, \% of DM & $20.6 \pm 1.9$ & $20.2 \pm 0.7$ & $27.3 \pm 0.9$ & $26.5 \pm 1.5$ \\
\hline Diet $\mathrm{TDN}_{1 \times}, \%$ of $\mathrm{DM}$ & $70.5 \pm 3.9$ & $70.5 \pm 3.9$ & $76.6 \pm 1.0$ & $76.6 \pm 1.0$ \\
\hline
\end{tabular}

${ }^{1}$ Nutrient composition of actual diets fed except for diet $\mathrm{TDN}_{1 \times}$, which was calculated using individual ingredient composition according to NRC (2001) summative equations.

${ }^{2}$ See Table 2 for ingredient composition.

${ }^{3}$ Calculated as $100-(\mathrm{CP} \%+\mathrm{NDF} \%+$ ether extract $\%+$ ash $\%)$.

management software (Feed Supervisor, Supervisor Systems, Dresser, WI). Daily pen DMI was measured as the difference between the as-fed feed offered and as-is feed refused (orts) multiplied by the DM content of the TMR.
Body weight and BCS (1 to 5 in 0.25 -unit increments; Wildman et al., 1982) were recorded on a pen basis on 3 consecutive days at the end of both the covariate and treatment periods. All cows from each pen were weighed and the average BW of the pen used for analy-

Table 2. Ingredient composition of grain mixes and treatment premixes

\begin{tabular}{|c|c|c|c|c|}
\hline Ingredient, $\%$ as fed & $\begin{array}{l}\text { Reduced } \\
\text { starch mix }\end{array}$ & $\begin{array}{l}\text { Normal } \\
\text { starch mix }\end{array}$ & $\begin{array}{l}\text { Control } \\
\text { premix }\end{array}$ & $\begin{array}{l}\text { Monensin } \\
\text { premix }\end{array}$ \\
\hline Dry ground shelled corn & 31.4 & 49.7 & - & - \\
\hline Soybean hull pellets & 31.3 & 11.0 & - & - \\
\hline Soybean meal - $48 \%$ & 21.0 & 23.0 & - & - \\
\hline Dried distillers grain & 9.3 & 9.2 & - & - \\
\hline Energy Booster $100^{1}$ & 3.4 & 3.3 & - & - \\
\hline Calcium carbonate & 1.3 & 1.3 & 54.3 & 53.3 \\
\hline Sodium bicarbonate & 0.8 & 0.8 & - & - \\
\hline Iodized salt & 0.7 & 0.7 & - & - \\
\hline Magnesium oxide & 0.5 & 0.5 & - & - \\
\hline Monocalcium phosphate & 0.3 & 0.3 & - & - \\
\hline Magnesium-potassium-sulfate ${ }^{2}$ & 0.2 & 0.2 & - & - \\
\hline Rice hulls & - & - & 40.0 & 40.0 \\
\hline Zinc sulfate & - & - & 1.5 & 1.5 \\
\hline Manganese sulfate & - & - & 1.3 & 1.3 \\
\hline Mineral oil & - & - & 1.3 & 1.3 \\
\hline Monensin ${ }^{3}$ & - & - & 0.0 & 1.0 \\
\hline Copper sulfate & - & - & 0.6 & 0.6 \\
\hline Vitamin E $(50 \%)$ & - & - & 0.4 & 0.4 \\
\hline Selenium $(0.8 \%)$ & - & - & 0.4 & 0.4 \\
\hline Vitamin $\mathrm{A} / \mathrm{D}_{3}(1,000 / 200)$ & - & - & 0.1 & 0.1 \\
\hline Vitamin $\mathrm{D}_{3}(500,000)$ & - & - & 0.02 & 0.02 \\
\hline Calcium iodate & - & - & 0.01 & 0.01 \\
\hline Cobalt carbonate & - & - & 0.005 & 0.005 \\
\hline
\end{tabular}


sis. Body weight change was calculated on a pen basis as the difference between the average BW at the end of the study and average BW at the end of the covariate period. Individual cows from each pen were assigned a BCS and then a pen average was used for analysis.

Cows were milked twice daily and milk yield was recorded daily on individual cows throughout the entire trial. Milk samples were taken on individual cows from a.m. and p.m. milkings during the last $3 \mathrm{~d}$ of the last week of the covariate period. Individual cow milk samples were obtained weekly from a.m. and p.m. milkings during the treatment period from all cows on the same 2 consecutive days and composited by pen and week with $55 \%$ of the composite from the a.m. milkings and $45 \%$ from the p.m. milkings according to the herd's proportional milk production. Milk composites were analyzed for fat, true protein, lactose, and MUN concentrations by infrared analysis and SCC by flow cytometry (AgSource Milk Analysis Laboratory, Menomonie, WI) using a CombiFoss $6600 \mathrm{FT}+/ \mathrm{FC}$ (Foss Electric, Hillerød, Denmark), with average daily yields of fat, protein, and lactose calculated from those data for each week. Yields of 3.5\% FCM, SCM, and ECM were calculated according to NRC (2001) equations. Actual-milk, 3.5\% FCM, SCM, and ECM feed efficiencies were calculated by pen and week using average daily pen-based yield and DMI data. Milk samples for FA composition were collected from a.m. and p.m. milkings on d 2 of milk sampling during the covariate period and d 1 of milk sampling during wk 2, 4, 8, and 12 of the treatment period and then composited by pen and week based on actual milk production. The composite milk samples were centrifuged at 17,800 $\times$ $g$ for 30 min at $8^{\circ} \mathrm{C}$, and milk fat was removed and stored at $-20^{\circ} \mathrm{C}$ until later FA analysis. Lipid extraction and FA methylation were performed according to methods described by Chouinard et al. (1999). Resulting FA methyl esters were injected in a gas chromatograph (Perkin Elmer Autosystem, Norwalk, CT) equipped with a $100-\mathrm{m}(0.25 \mathrm{~mm}$ i.d.) WCOT (wallcoated open tubular) fused-silica capillary column wall coated with CP-Sil 88 (Chrompack \#CP7489, Varian Inc., Walnut Creek, CA). Helium was the carrier gas. Each sample was analyzed under 3 different conditions. First, total FA profile was determined by a temperature gradient run $\left(50\right.$ to $190^{\circ} \mathrm{C}$ at $\left.4^{\circ} \mathrm{C} / \mathrm{min}\right)$. Second, an isothermal run $\left(160^{\circ} \mathrm{C}\right)$ was used to separate cisand trans-octadecenoic FA. Third, another isothermal run $\left(180^{\circ} \mathrm{C}\right)$ was used to separate cis-9 octadecenoic FA peaks. Peaks were identified utilizing individual FA from Supelco Inc. (Bellefonte, PA), Sigma Chemical Co. (St. Louis, MO), and Matreya Inc. (Pleasant Gap, PA). Response factors for each FA methyl ester were obtained based on analysis of certified butterfat (CRM
164, Commission of the European Communities, Community Bureau of Reference, Brussels, Belgium) and applied to adjust individual areas' mass proportion. Response factors for FA not in the certified butterfat standard were calculated as an average of the certified FA that eluted before and after them.

Estimated diet energy concentrations were calculated by summing the $\mathrm{NE}_{\mathrm{L}}$ (Mcal) from milk production [milk yield $\times(0.0929 \times$ fat $\%+0.0563 \times$ protein $\%$ $+0.0395 \times$ lactose \%)], required for maintenance $(0.08$ Mcal of $\mathrm{NE}_{\mathrm{L}} / \mathrm{kg}$ of $\mathrm{BW} \times \mathrm{BW}^{0.75}$ ) and $\mathrm{BW}$ change (BW change $\times 5.34$ Mcal of $\mathrm{NE}_{\mathrm{L}} / \mathrm{kg}$ of $\left.\mathrm{BW}\right)(\mathrm{NRC}$, 2001), and dividing the sum by DMI. Samples of TMR, corn silage, alfalfa silage, and concentrate mixes were obtained weekly and composited by 2 -wk periods for analysis. Samples of DGSC and soy hulls were obtained at the beginning and end of the study. Samples for determination of nutrient composition were dried at $60^{\circ} \mathrm{C}$ for $48 \mathrm{~h}$ in a forced-air oven to determine $\mathrm{DM}$ content, ground to pass a 1-mm Wiley mill (Arthur H. Thomas, Philadelphia, PA) screen, and composited before sending to Dairyland Laboratories Inc. (Arcadia, WI) for analysis of $\mathrm{OM}$ (ashing at $600^{\circ} \mathrm{C}$ for $2 \mathrm{~h}$ ), CP, ether extract using diethyl ether (AOAC International, 1995), NDF using $\alpha$-amylase and sodium sulfite (Van Soest et al., 1991), and starch (Bach Knudsen, 1997; YSI Biochemistry Analyzer, YSI Inc., Yellow Springs, $\mathrm{OH})$. Particle size of TMR, corn silage, and alfalfa silage samples was determined as described by Kononoff et al. (2003). Particle size of the concentrate mixtures and DGSC was determined by dry sieving using Tyler Ro-Tap Shaker (model RX-29, Tyler, Mentor, OH) and sieves with 4,760-, 2,380-, 1,190-, 595-, 297-, 149-, and $63-\mu \mathrm{m}$ apertures plus bottom pan with mean particle size calculated using a log normal distribution (Baker and Herrman, 2002).

Fecal samples were collected at 0600 and $1600 \mathrm{~h}$ during the last $2 \mathrm{~d}$ of the last week of the covariate period and wk 6 and 12 of the treatment period from each cow in each pen by rectal grab and composited by pen at each time point. Samples were frozen at $-20^{\circ} \mathrm{C}$, dried at $60^{\circ} \mathrm{C}$ for $48 \mathrm{~h}$ in a forced-air oven, ground to pass a 1-mm Wiley mill (Arthur H. Thomas) screen, and analyzed for starch concentrations (Bach Knudsen, 1997; YSI Biochemistry Analyzer, YSI Inc.) at Dairyland Laboratories Inc. Total-tract starch digestibility was calculated from fecal starch concentration using the equation $[100 \times(0.9997-0.0125 \times$ fecal starch, $\%$ DM)] (Ferraretto and Shaver, 2012).

\section{Statistical Analysis}

Three cows were removed from the study because of health issues, with one cow having a dilated cecum, 
Table 3. Ingredient nutrient composition

\begin{tabular}{|c|c|c|c|c|c|c|}
\hline $\begin{array}{l}\text { Nutrient, } \\
\% \text { of DM }\end{array}$ & $\begin{array}{l}\text { Corn } \\
\text { silage }\end{array}$ & $\begin{array}{l}\text { Alfalfa } \\
\text { silage }\end{array}$ & $\begin{array}{l}\text { Reduced } \\
\text { starch mix }\end{array}$ & $\begin{array}{l}\text { Normal } \\
\text { starch mix }\end{array}$ & $\begin{array}{l}\text { Ground } \\
\text { corn }\end{array}$ & $\begin{array}{l}\text { Soy hull } \\
\text { pellets }\end{array}$ \\
\hline DM, $\%$ as fed & $33.8 \pm 1.8$ & $43.4 \pm 1.9$ & $89.6 \pm 0.6$ & $90.0 \pm 0.3$ & $89.1 \pm 0.2$ & $91.1 \pm 0.2$ \\
\hline $\mathrm{CP}$ & $7.6 \pm 0.2$ & $21.9 \pm 0.4$ & $19.5 \pm 1.1$ & $20.0 \pm 1.0$ & $9.7 \pm 0.2$ & $15.3 \pm 0.6$ \\
\hline Ether extract & $5.0 \pm 1.3$ & $4.5 \pm 0.5$ & $5.3 \pm 0.5$ & $6.3 \pm 0.5$ & $4.4 \pm 0.4$ & $4.2 \pm 1.2$ \\
\hline Ash & $4.7 \pm 0.2$ & $10.0 \pm 0.1$ & $7.0 \pm 0.5$ & $7.0 \pm 0.9$ & $2.3 \pm 0.5$ & $5.0 \pm 0.1$ \\
\hline Starch & $35.5 \pm 2.5$ & $1.9 \pm 0.3$ & $19.2 \pm 1.5$ & $35.0 \pm 2.4$ & $66.4 \pm 0.8$ & $2.1 \pm 2.0$ \\
\hline
\end{tabular}

${ }^{1}$ Calculated as $100-(\mathrm{CP} \%+\mathrm{NDF} \%+$ ether extract $\%+$ ash \%).

another having digestive upset, and another having chronic mastitis. Outlier analysis was performed on all data using PROC UNIVARIATE (SAS Institute, 2004 ) with outliers considered when outside of the $95 \%$ confidence interval of the data set. Milk fat percentage data from wk 6 of the treatment period was found to be an outlier. Data affected included milk fat yield, 3.5\% FCM, ECM, SCM, and their associated feed efficiencies. The data were removed before analysis and no treatment comparisons were made for that week; data for wk 6 within figures were determined by averaging wk 5 and 7 . In addition, MUN data from wk 12 of the treatment period was considered an outlier, removed before analysis, and no treatment comparisons made for that week. Week 11 data for MUN were used in the figures to replace wk 12 data.

Data were analyzed with PROC MIXED (SAS Institute, 2004) as a completely randomized design with a factorial arrangement of treatments with covariate adjustment. Pen was the experimental unit. The milk and DMI data from the last 2 wk of the covariate period were used for covariate adjustment in the model. The model included the effects of $\mathrm{S}, \mathrm{M}, \mathrm{S} \times \mathrm{M}$ interaction, week, $\mathrm{S} \times$ week, $\mathrm{M} \times$ week, and $\mathrm{S} \times \mathrm{M} \times$ week interactions as fixed effects, and pen within treatment as a random effect. Week of treatment was included in the model as a repeated measure using the first-order autoregressive covariance structure, which provided the best fit according to Sawa's Bayesian information criterion. No covariate or repeated-measures effects were included in the analysis of BW, BW change, BCS, BCS change, or estimated diet energy concentration data. Degrees of freedom were calculated using the KenwardRoger option. Least squares means were determined and treatment means within weeks compared using the SLICE option. Statistical significance and trends were considered at $P \leq 0.05$ and $P>0.05$ to $P \leq 0.10$, respectively.

\section{RESULTS AND DISCUSSION}

Nutrient composition of the diets and ingredients is presented in Tables 1 and 3, respectively. Particle size distribution of the forages and diets are presented in Table 4. Starch and NDF concentrations averaged $20.4 \%$ and $34.9 \%$ for the RS diets and $26.9 \%$ and $28.5 \%$ for NS diets, respectively. Previous studies (Gencoglu et al., 2010; Ferraretto et al., 2011) reported similar starch and NDF concentrations for RS and NS diets. The NFC concentrations were 33.2 and $39.5 \%$ for RS and NS diets, respectively. Differences in starch, NDF, and NFC concentrations between the diets were due to partial replacement of DGSC with soy hulls. The NS and RS diets had similar contents of CP (18.1\% of DM on average) and ether extract (5.9\% of DM on average). Forage NDF was $19.5 \%$ of DM for all diets. Particle size was similar between TMR treatments.

Lactation performance results are presented in Tables 5 and 6. Mean DMI $(27.0 \mathrm{~kg} / \mathrm{d})$ was unaffected by treatment: $\mathrm{S}(P=0.53), \mathrm{M}(P=0.33)$, and $\mathrm{S} \times$

Table 4. Particle length distribution of forages and treatment TMR

\begin{tabular}{|c|c|c|c|c|c|c|}
\hline \multirow{3}{*}{$\begin{array}{l}\text { Retained, } \\
\% \text { as fed }\end{array}$} & \multicolumn{2}{|c|}{ Forage } & \multicolumn{4}{|c|}{ TMR } \\
\hline & \multirow{2}{*}{$\begin{array}{l}\text { Corn } \\
\text { silage }\end{array}$} & \multirow{2}{*}{$\begin{array}{l}\text { Alfalfa } \\
\text { silage }\end{array}$} & \multicolumn{2}{|c|}{ Reduced starch } & \multicolumn{2}{|c|}{ Normal starch } \\
\hline & & & Control & Monensin & Control & Monensin \\
\hline$>19 \mathrm{~mm}$ & $4.5 \pm 1.2$ & $11.9 \pm 3.2$ & $3.2 \pm 0.6$ & $4.0 \pm 0.8$ & $3.2 \pm 0.6$ & $3.7 \pm 1.1$ \\
\hline $8-19 \mathrm{~mm}$ & $74.8 \pm 1.7$ & $62.4 \pm 1.8$ & $45.5 \pm 1.0$ & $47.1 \pm 3.1$ & $43.1 \pm 4.6$ & $44.7 \pm 2.8$ \\
\hline $1.2-8 \mathrm{~mm}$ & $20.5 \pm 1.7$ & $23.2 \pm 2.3$ & $35.3 \pm 1.2$ & $32.9 \pm 2.0$ & $36.3 \pm 2.5$ & $34.4 \pm 2.4$ \\
\hline$<1.2 \mathrm{~mm}$ & $0.2 \pm 0.2$ & $2.5 \pm 0.5$ & $16.1 \pm 1.5$ & $16.0 \pm 1.9$ & $17.5 \pm 2.9$ & $17.2 \pm 2.0$ \\
\hline
\end{tabular}


$\mathrm{M}$ interaction $(P=0.97)$. We did detect interactions, however, for DMI: $\mathrm{S} \times$ week $(P<0.01), \mathrm{M} \times$ week (Figure $1 ; P<0.01$ ), and a tendency for an $\mathrm{S} \times \mathrm{M}$ $\times$ week interaction $(P=0.08)$. Dry matter intake was greater for $\mathrm{C}$ than $\mathrm{M}$ during wk 4,6 , and $9(P<$ $0.05)$ and greater for NS than RS during wk 1 and 2 $(P<0.05)$ but similar thereafter. During the first 2 wk of treatment, RS-C and RS-M had lower intakes than NS-C and NS-M; however, during wk 4, 6, and 9, RS-C and NS-C had greater intakes than RS-M and NS-M, and all treatments had similar intakes for wk 10 through 12 . The $\mathrm{M} \times$ week interaction indicated a more consistent DMI for $\mathrm{M}$ than for $\mathrm{C}$ throughout the study (Figure 1; $P<0.01$ ). This may be due to the use of monensin in the covariate diet, with monensin having a residual effect in the control treatment until approximately treatment wk 4 . We observed an overall numerical decrease $(P=0.33)$ in DMI of $0.4 \mathrm{~kg} / \mathrm{d}$ for $\mathrm{M}$ compared with $\mathrm{C}$, which is of similar magnitude to the results of a recent meta-analysis that showed a $0.3 \mathrm{~kg} / \mathrm{d}$ decrease in DMI from M supplementation (Duffield et al., 2008). Ipharraguerre and Clark (2003b) reported variable effects of M on DMI. They reported decreased DMI in 2 out of the 7 studies reviewed. This variation in the DMI response to M could be due to many factors including, but not limited to, stage of lactation of study animals, length of time that data were collected, and number of animals on study. Pre-experiment power to find difference of $1 \mathrm{~kg}$ of DMI, $1.5 \mathrm{~kg}$ of milk yield, and 0.2 percentage units of milk fat content were calculated using 8 pens for the main effect level of starch or monensin, variance estimates from previous studies performed in pen-based continuous lactation studies, and an $\alpha$ of 0.05 . The power calculated for main effects on DMI, milk yield, and fat content was 92, 85, and $81 \%$, respectively, and was not considered limiting to find differences between treatment main effects. The power to find significant treatment interactions with 4 pens per treatment was lower, with a power of 67 , 56 , and $52 \%$ for DMI, milk yield, and milk fat content, respectively, and was less than ideal to find significant interaction effects. This may lead to higher occurrence of type 2 errors and concluding no significant interaction effect when there would be a significant interaction effect with sufficient power. Milk fat percentage (Table 5) may not have been significantly affected by the treatment interaction because of the reduced power and is discussed later. The other variables in Table 5 do not appear to be affected. The low power was likely due to limited pen numbers and thus sample size available for the study.

Experiments by Gencoglu et al. (2010) and Ferraretto et al. (2011) reported an increase in DMI for RS diets attributed to a reduction in propionate production and increased NDF digestibility; however, a review by Ipharraguerre and Clark (2003a) reported that DMI was not affected by partially replacing grain with soybean hulls in 13 of 15 studies. In contrast, Ranathunga et al. (2010) observed reduced DMI for RS diets when dried distillers grain and soy hulls incrementally replaced DGSC and soybean meal. The DMI decrease observed by Ranathunga et al. (2010) was attributed to the increased dietary NDF content for RS diets causing a rumen fill limitation of DMI and the increase in dietary unsaturated FA content with greater inclusion of distillers grain that may cause a hypophagic effect (Allen et al., 2005). The reduction in DMI during the first $2 \mathrm{wk}$ of the treatment period for cows fed the RS diet was likely due to cows adjusting from the NS diet that was fed during the covariate period to the RS diet. Gencoglu et al. (2010) and Ferraretto et al. (2011) did not observe this decrease in DMI.

Cows fed NS produced $1.5 \mathrm{~kg}$ more milk $(P=0.01)$ per day than cows fed RS. Monensin increased $(P=$ 0.01 ) milk yield by $1.3 \mathrm{~kg} / \mathrm{d}$ compared with $\mathrm{C}$. We found an $\mathrm{M} \times$ week interaction (Figure $2 ; P=0.03$ ) such that M-supplemented cows produced more milk than $\mathrm{C}$ cows as the treatment period progressed. Gencoglu et al. (2010), using only multiparous cows and cows in earlier lactation than the current study, reported similar milk yields for RS and NS with soy hulls partially replacing DGSC. In other studies (Batajoo and Shaver, 1994; Beckman and Weiss, 2005), feeding RS diets formulated with a combination of soy hulls and either wheat middlings or cottonseed hulls to partially replace DGSC did not affect milk yield. Ranathunga et al. (2010), using a combination of dried distillers grain and soy hulls to incrementally replace DGSC and soybean meal, also observed no effect on milk yield, even with reduced DMI for RS. The increase in milk yield from M supplementation is well substantiated by literature reviews with reported increases of $1.5 \mathrm{~kg} / \mathrm{d}$ (Ipharraguerre and Clark, 2003b) and $0.7 \mathrm{~kg} / \mathrm{d}$ (Duffield et al., 2008). Monensin is thought to increase milk yield by increasing the production of propionate, a glucogenic precursor, as a proportion of total VFA from rumen fermentation (Ramanzin et al., 1997), which increases glucose and lactose synthesis and thus milk yield.

We detected a tendency for an $\mathrm{S} \times \mathrm{M}$ interaction for actual milk feed efficiency (AMFE, Figure 3; $P=0.08$ ) such that M increased AMFE more for NS than for RS. The interaction between $\mathrm{M}$ and $\mathrm{S}$ may be related to greater starch intake, amount of starch digested ruminally, and propionate production for NS compared with RS. Both $\mathrm{S} \times$ week and $\mathrm{M} \times$ week interactions were detected for AMFE. Cows fed $M$ had increased $(P<$ 0.05) AMFE during 7 of the $12 \mathrm{wk}$ on treatment. Cows fed NS had greater $(P<0.05)$ AMFE during the last 4 
Table 5. Effect of reduced and normal starch diets with and without monensin on lactation performance

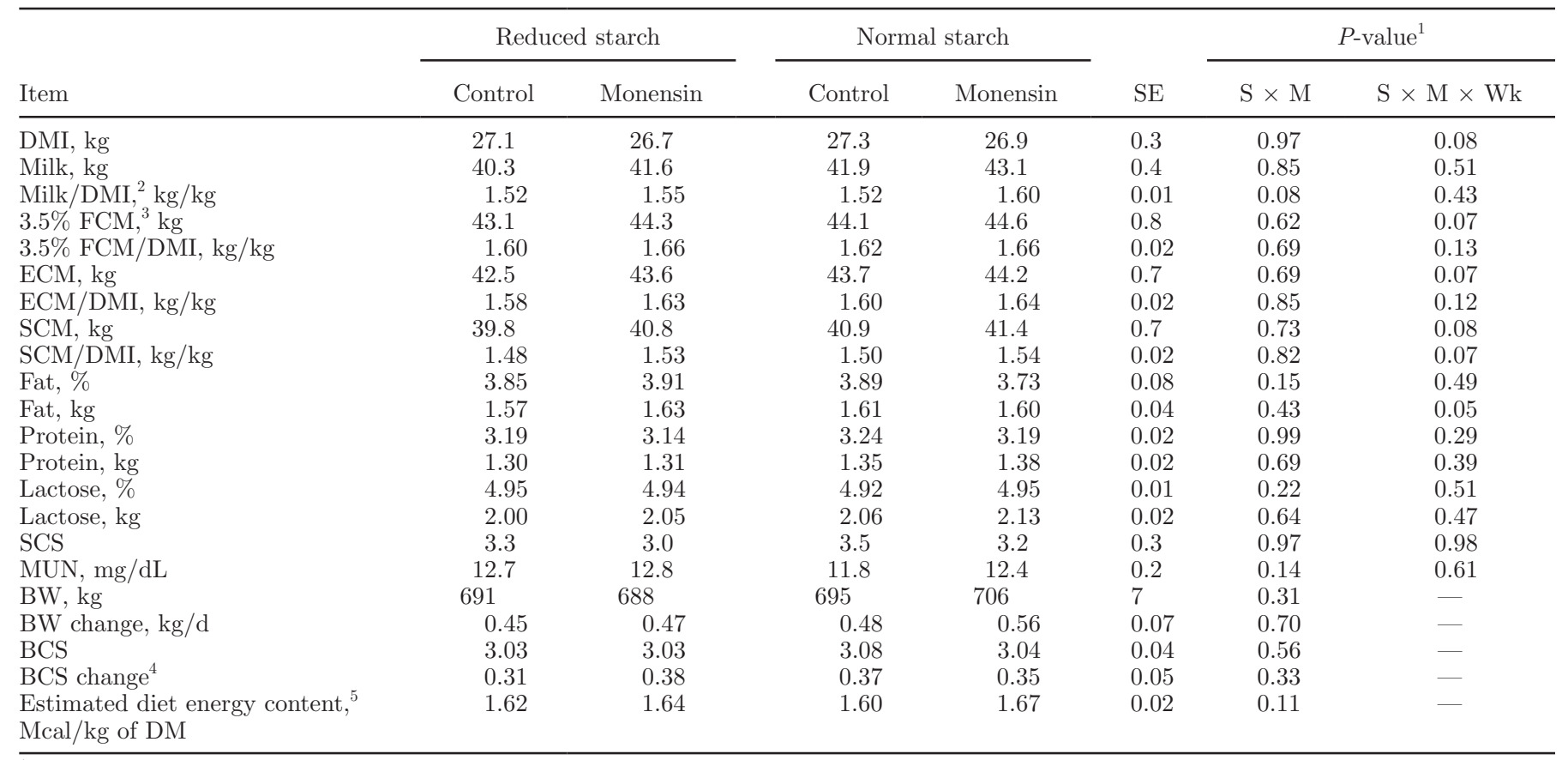

${ }^{1} \mathrm{~S}=$ starch; $\mathrm{M}=$ monensin.

${ }^{2}$ Actual milk, 3.5\% FCM, SCM, and ECM feed conversions were calculated using average daily pen-based yield and DMI data.

${ }^{3}$ Yield of $3.5 \% \mathrm{FCM}=0.432 \times$ milk yield $+16.23 \times$ fat yield, $\mathrm{ECM}=12.82 \times$ fat yield $+7.13 \times$ protein yield $+0.323 \times$ milk yield, and SCM $=$ milk yield $\times[(12.24 \times$ fat $\% \times 0.01)+(7.1 \times$ protein $\% \times 0.01)+(6.35 \times$ lactose $\% \times 0.01)-0.0345]$ as according to NRC $(2001)$ equations. ${ }^{4} \mathrm{BCS}$ change calculated by difference of covariate BCS and treatment BCS.

${ }^{5}$ Estimated diet energy content $=\left[0.08 \times \mathrm{BW}, \mathrm{kg}^{0.75}+\mathrm{BW}\right.$ change $\times 5.34+$ milk yield, $\mathrm{kg} \times(0.0929 \times$ fat $\%+0.0563 \times$ protein $\%+0.0395$ $\times$ lactose \%)]/DMI, kg (NRC, 2001).

wk on treatment, which suggests that longer times may be required to observe differences in AMFE between dietary starch concentrations. Gencoglu et al. (2010) also observed an $\mathrm{S} \times$ week interaction; however, $\mathrm{AMFE}$ was greater for NS than RS during the first 6 wk on treatment and was not different in the final $6 \mathrm{wk}$ on treatment. Duffield et al. (2008) reported from a metaanalysis that $\mathrm{M}$ increased AMFE by $2.5 \%$, whereas $\mathrm{M}$ increased AMFE by $3.9 \%$ in the current study.

No $\mathrm{M}$ or $\mathrm{S}$ effects on $3.5 \% \mathrm{FCM}$, ECM, or SCM yields were detected; however, there was an $\mathrm{M} \times$ week interaction $(P<0.02)$ for all component-corrected milk yields, with monensin supplementation increasing yields during wk 7 and 8 of the treatment period. A tendency $(P=0.08)$ for a $\mathrm{S} \times \mathrm{M} \times$ week interaction was observed for all component-corrected milk yields such that yields were similar for all treatments through wk 5 or 6 , and then NS-M had the highest, NS-C and RS-M were intermediate, and RS-C had the lowest yields for the remainder of the study. This interaction may indicate that the effect of monensin could depend on diet composition, but also that longer continuous lactation experiments rather than short-term Latin square trials are needed to observe these differences.
Gencoglu et al. (2010) reported an average increase of $2.4 \mathrm{~kg} / \mathrm{d}$ in component-corrected milk yields for NS compared with RS. The 4\% FCM and ECM yields were unaffected by feeding RS versus NS diets in trials by Batajoo and Shaver (1994) and Beckman and Weiss (2005), respectively. Martinez et al. (2009) reported no effect of monensin on $3.5 \%$ FCM yield for cows fed diets with supplemented monensin at 2 dietary forage concentrations, but used only 4 -wk periods in a Latin square design, which may not have allowed adaptation to $\mathrm{M}$ or detection of a response.

We observed $\mathrm{S} \times$ week and $\mathrm{M} \times$ week interactions $(P<0.01)$ and a tendency $(P=0.07)$ for an $\mathrm{S} \times \mathrm{M}$ $\times$ week interaction for $3.5 \% \mathrm{FCM} / \mathrm{DMI}$, ECM/DMI, and SCM/DMI efficiencies. Component-corrected milk feed efficiencies were greater for RS than NS during the first 2 wk on treatment, similar from wk 3 to 8 , and then greater for NS than RS during the final 2 wk on treatment. In contrast, Ranathunga et al. (2010) observed a linear increase in feed efficiency (ECM/DMI) for cows fed RS diets as distillers grain and soy hulls incrementally replaced DGSC and soybean meal. This increase was due to a decrease in DMI and no change in ECM production with RS diets. For the $\mathrm{M} \times$ week 


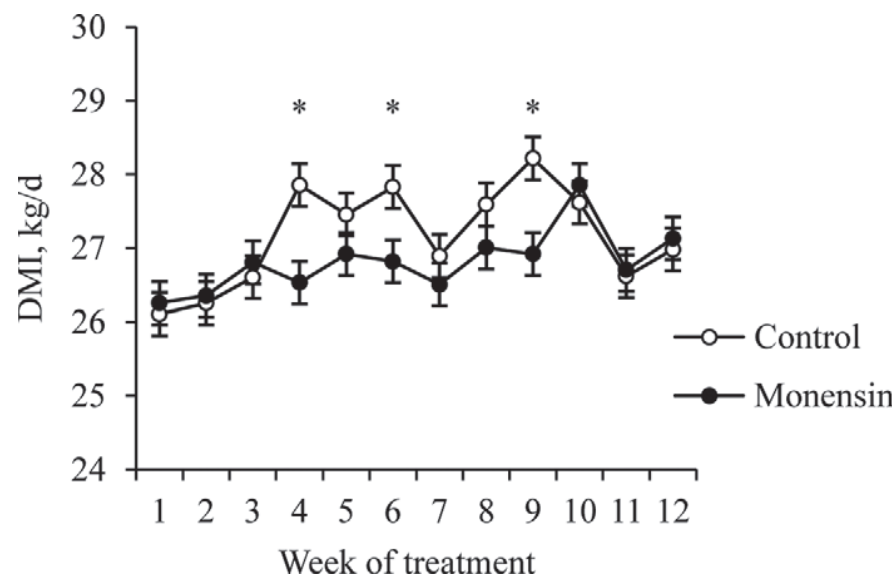

Figure 1. Covariate-adjusted least squares means for weekly DMI $(\mathrm{kg} / \mathrm{d})$ of lactating cows fed diets with and without monensin. Control and monensin diets contained 0 and $18 \mathrm{~g}$ of monensin/t of TMR DM, respectively. Monensin $\times$ week, $P<0.01 ; \mathrm{SEM}=0.3 \mathrm{~kg}$. Means within the same week were significantly different at $P \leq 0.05\left(^{*}\right)$.

interaction, component-corrected milk feed efficiencies were similar during the first $3 \mathrm{wk}$ on treatment, greater for $\mathrm{M}$ during wk 4, 7, 8, and 9, but similar during the

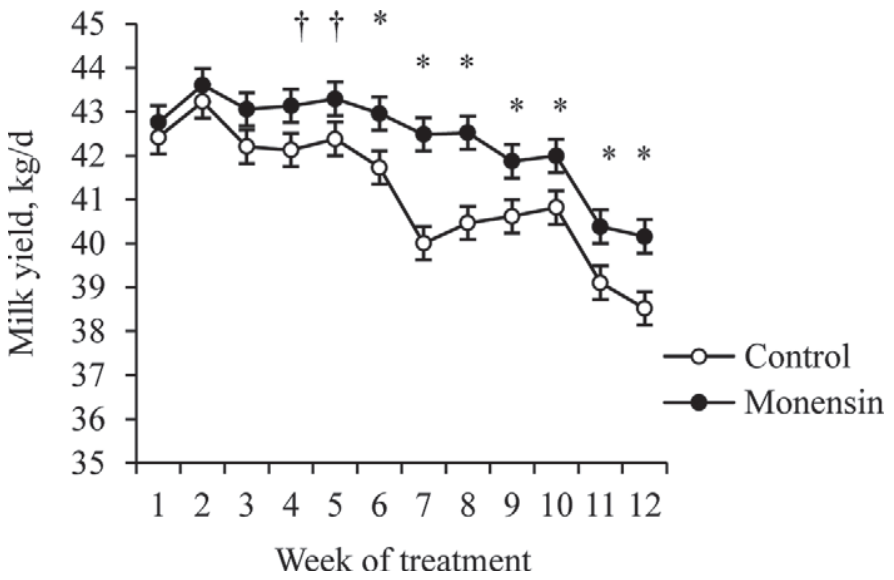

Figure 2. Covariate-adjusted least squares means for weekly milk production $(\mathrm{kg} / \mathrm{d})$ of lactating cows fed diets with and without monensin. Control and monensin diets contained 0 and $18 \mathrm{~g}$ of monensin/t of diet DM, respectively. Monensin $\times$ week, $P=0.03 ; \mathrm{SEM}=0.4 \mathrm{~kg}$. Means within the same week were significantly different at $P \leq 0.05$ $\left(^{*}\right)$ or tended to differ at $0.05<P \leq 0.10(\dagger)$.

last $3 \mathrm{wk}$ on treatment. The $\mathrm{S} \times \mathrm{M} \times$ week interaction for SCM/DMI was similar to the $\mathrm{M} \times$ week interactions in that the treatments were similar in the first 3

Table 6. Effects of the main effects of dietary starch and monensin on lactation performance

\begin{tabular}{|c|c|c|c|c|c|c|c|c|c|}
\hline \multirow[b]{2}{*}{ Variable } & \multicolumn{2}{|c|}{ Starch } & \multicolumn{2}{|c|}{ Monensin } & \multirow[b]{2}{*}{ SEM } & \multicolumn{4}{|c|}{$P$-value ${ }^{1}$} \\
\hline & Reduced & Normal & $0 \mathrm{~g} / \mathrm{t}$ & $18 \mathrm{~g} / \mathrm{t}$ & & $\mathrm{S}$ & M & $\mathrm{S} \times \mathrm{Wk}$ & $\mathrm{M} \times \mathrm{Wk}$ \\
\hline DMI, kg/d & 26.9 & 27.1 & 27.2 & 26.8 & 0.2 & 0.53 & 0.33 & $<0.01$ & $<0.01$ \\
\hline Milk, kg/d & 41.0 & 42.5 & 41.1 & 42.4 & 0.3 & 0.01 & 0.01 & 0.51 & 0.03 \\
\hline Milk/DMI, ${ }^{2} \mathrm{~kg} / \mathrm{kg}$ & 1.54 & 1.56 & 1.52 & 1.58 & 0.01 & 0.11 & $<0.01$ & 0.01 & $<0.01$ \\
\hline $3.5 \% \mathrm{FCM}^{3}{ }^{3} \mathrm{~kg} / \mathrm{d}$ & 43.7 & 44.4 & 43.6 & 44.4 & 0.6 & 0.42 & 0.30 & 0.20 & $<0.01$ \\
\hline $3.5 \%$ FCM/DMI, kg/kg & 1.63 & 1.64 & 1.61 & 1.66 & 0.01 & 0.73 & 0.04 & $<0.01$ & $<0.01$ \\
\hline $\mathrm{ECM}, \mathrm{kg} / \mathrm{d}$ & 43.0 & 44.0 & 43.1 & 43.9 & 0.5 & 0.25 & 0.29 & 0.32 & 0.02 \\
\hline ECM/DMI, kg/kg & 1.60 & 1.62 & 1.59 & 1.64 & 0.01 & 0.40 & 0.03 & $<0.01$ & $<0.01$ \\
\hline $\mathrm{SCM}, \mathrm{kg} / \mathrm{d}$ & 40.3 & 41.1 & 40.3 & 41.1 & 0.5 & 0.28 & 0.31 & 0.26 & 0.02 \\
\hline $\mathrm{SCM} / \mathrm{DMI}, \mathrm{kg} / \mathrm{kg}$ & 1.50 & 1.52 & 1.49 & 1.53 & 0.01 & 0.54 & 0.05 & $<0.01$ & $<0.01$ \\
\hline Fat, $\%$ & 3.88 & 3.81 & 3.87 & 3.82 & 0.05 & 0.36 & 0.52 & 0.08 & 0.31 \\
\hline Fat, kg/d & 1.60 & 1.61 & 1.59 & 1.61 & 0.03 & 0.85 & 0.56 & 0.05 & $<0.01$ \\
\hline Protein, \% & 3.17 & 3.22 & 3.22 & 3.17 & 0.01 & 0.01 & 0.02 & 0.77 & 0.03 \\
\hline Protein, kg/d & 1.30 & 1.36 & 1.32 & 1.34 & 0.01 & $<0.011$ & 0.37 & 0.60 & 0.05 \\
\hline Lactose, $\%$ & 4.94 & 4.94 & 4.93 & 4.94 & 0.01 & 0.71 & 0.60 & 0.04 & 0.27 \\
\hline Lactose, $\mathrm{kg} / \mathrm{d}$ & 2.03 & 2.10 & 2.03 & 2.09 & 0.02 & 0.02 & 0.02 & 0.15 & 0.02 \\
\hline $\mathrm{SCS}^{4}$ & 3.1 & 3.3 & 3.4 & 3.1 & 0.2 & 0.63 & 0.33 & 0.87 & 0.41 \\
\hline MUN, mg/dL & 12.7 & 12.1 & 12.2 & 12.6 & 0.1 & $<0.01$ & 0.06 & $<0.01$ & $<0.01$ \\
\hline $\mathrm{BW}, \mathrm{kg}$ & 690 & 701 & 693 & 697 & 5 & 0.12 & 0.52 & - & - \\
\hline BW change, kg/d & 0.46 & 0.52 & 0.47 & 0.52 & 0.05 & 0.45 & 0.53 & - & - \\
\hline $\mathrm{BCS}$ & 3.03 & 3.06 & 3.05 & 3.04 & 0.03 & 0.48 & 0.65 & - & - \\
\hline BCS change $^{5}$ & 0.34 & 0.36 & 0.34 & 0.36 & 0.03 & 0.70 & 0.59 & - & - \\
\hline $\begin{array}{l}\text { Estimated diet energy content, } \\
\text { Mcal/kg of DM }\end{array}$ & 1.63 & 1.64 & 1.61 & 1.66 & 0.01 & 0.69 & $<0.01$ & - & - \\
\hline
\end{tabular}

${ }^{1} \mathrm{~S}=$ starch; $\mathrm{M}=$ monensin.

${ }^{2}$ Actual milk, 3.5\% FCM, SCM, and ECM efficiencies were calculated using average daily pen-based yield and DMI data.

${ }^{3}$ Yield of $3.5 \% \mathrm{FCM}=0.432 \times$ milk yield $+16.23 \times$ fat yield $\mathrm{ECM}=12.82 \times$ fat yield $+7.13 \times$ protein yield $+0.323 \times$ milk yield, and SCM $=$ milk yield $\times[(12.24 \times$ fat $\% \times 0.01)+(7.1 \times$ protein $\% \times 0.01)+(6.35 \times$ lactose $\% \times 0.01)-0.0345]$ as according to NRC $(2001)$ equations.

${ }^{4} \mathrm{SCS}=\log$ base $2 \times(\mathrm{SCC} / 100)+3$.

${ }^{5} \mathrm{BCS}$ change calculated by difference of covariate BCS and treatment BCS.

${ }^{6}$ Estimated diet energy content $=\left[0.08 \times \mathrm{BW}, \mathrm{kg}^{0.75}+\mathrm{BW}\right.$ change $\times 5.34+$ milk yield, $\mathrm{kg} \times(0.0929 \times$ fat $\%+0.0563 \times$ protein $\%+0.0395$ $\times$ lactose \%)]/DMI, kg (NRC, 2001). 


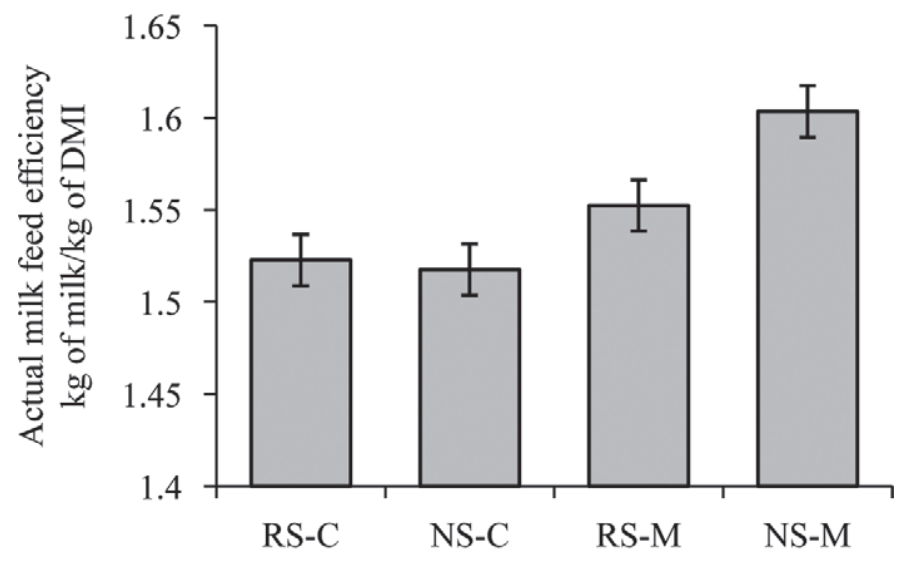

Treatment

Figure 3. Covariate-adjusted means for actual milk yield feed efficiency (AMFE; $\mathrm{kg}$ of milk/ $\mathrm{kg}$ of DMI) of lactating dairy cows fed diets with and without monensin and 2 starch concentrations. RS-C $=$ reduced starch diet without monensin; RS-M = reduced starch diet with monensin; NS-C = normal starch diet without monensin; NS-M $=$ normal starch diet with monensin. Starch $\times$ monensin, $P=0.08$; $\mathrm{SEM}=0.3$.

wk on treatment, RS-M and NS-M were greater than RS-C and NS-C from wk 4 through 9, and then similar thereafter. Similar to previous reports (Duffield et al., 2008), monensin supplementation increased $(P<$ $0.05) 3.5 \% \mathrm{FCM} / \mathrm{DMI}$ and ECM/DMI efficiencies by an average of $0.05 \mathrm{~kg}$ of yield $/ \mathrm{kg}$ of DMI or 3.1 and $3.4 \%$, respectively, over controls. Previous research has reported increases in efficiencies on average of $3.6 \%$ on low forage diets $(<60 \%$ forage $\mathrm{DM})$ and $11.4 \%$ on high forage diets $(>60 \%$ forage $\mathrm{DM})$ with $\mathrm{M}$ supplementation (Ipharraguerre and Clark, 2003b).

Overall means for milk fat percentage and yield were unaffected by treatment $(P>0.10)$, which differs from other studies with dietary $M$ inclusion (Ipharraguerre and Clark, 2003b) or differing dietary starch concentrations (Beckman and Weiss, 2005). However, Duffield et al. (2008) reported that $\mathrm{M}$ decreased milk fat content by 0.12 percentage units but did not affect fat yield. The $\mathrm{S} \times \mathrm{M}$ interaction for milk fat percentage approached a tendency $(P=0.15)$, with NS-M having a numerically lower milk fat percentage of $3.73 \%$ compared with 3.85 , 3.91, and 3.89 for RS-C, RS-M, and NS-C, respectively, and may indicate that monensin reduced the milk fat content of cows fed NS diets but not RS diets. Duffield et al. (2008) did not find a significant effect of dietary starch on milk fat percentage. The numerical difference between milk fat content for NS-M and the average of the other treatments was 0.15 percentage units, which is similar to Duffield et al. (2008). The low power for interactions may have reduced the ability to find this interaction to be significant. A linear increase in milk fat percentage was observed by Beckman and Weiss (2005) when diets increasing in NDF to starch ratio from 0.74 to 1.27 were fed. The RS and NS diets in the current study had NDF to starch ratios of 1.70 and 1.06, respectively. There tended to be an $\mathrm{S} \times$ week interaction $(P=0.08)$ for milk fat content such that fat percentage was greater for RS than NS during the first 2 wk on treatment. During the first 2 wk on treatment, cows fed RS diets had lower DMI, and thus reduced energy intake, which likely resulted in cows mobilizing body reserves to meet energy requirements. Mean energy balance during wk 1 and 2, as calculated using NRC (2001) equations, were $-1.5 \mathrm{Mcal} / \mathrm{d}$ and 0.3 Mcal/d per cow for RS and NS, respectively. Similar to milk yield, we observed an $\mathrm{M} \times$ week interaction $(P<0.01)$ for milk fat yield such that $\mathrm{M}$ increased fat yield throughout the treatment period. Additionally, we found an $\mathrm{S} \times$ week interaction $(P=0.05)$ for milk fat yield such that fat yield increased slightly over time for NS. An interaction of $\mathrm{S} \times \mathrm{M} \times$ week $(P=0.05)$ was observed for milk fat yield, with reduced fat yield for RS-C from wk 7 through 12 on treatment and inconsistent trends for the other treatments during the study.

Milk protein percentage and yield were greater $(P=$ $0.01)$ for NS than RS and likely due to greater ruminal microbial protein yield for NS (Oba and Allen, 2003). Ferraretto et al. (2011) also reported an increase in milk protein yield for NS compared with RS. Compared with $\mathrm{M}$, milk protein percentage was greater $(P=0.02)$ for $\mathrm{C}$; however, no difference in protein yield was observed $(P=0.37)$. We found an $\mathrm{M} \times$ week interaction for milk protein yield that was similar to the interactions observed for FCM, ECM, and SCM yields with M increasing $(P=0.05)$ protein yields during wk 7 and 8 on treatment. Ipharraguerre and Clark (2003b) and Duffield et al. (2008) also observed a decrease in milk protein percentage with M supplementation; however, milk protein yield was either unaffected (Ipharraguerre and Clark, 2003b) or increased (Duffield et al., 2008). A decrease in protein percentage may be explained as a possible dilution effect from increased milk yield or due to a numerical decrease in DMI that reduced fermentable carbohydrates needed for microbial protein synthesis and (or) reduced dietary protein intake. The diets fed were not formulated based on metabolizable protein or amino acid needs, which if done could offset the reduced DMI and nutrient intakes by cows fed M.

Lactose percentage was unaffected by treatment but lactose yield was increased for $\mathrm{M}$ compared with $\mathrm{C}$ and for NS compared with RS $(P=0.02)$. The MUN was $0.6 \mathrm{mg} / \mathrm{dL}$ greater $(P<0.01)$ for RS than for NS. Monensin-supplemented cows tended $(P=0.06)$ to have $0.4 \mathrm{mg} / \mathrm{dL}$ greater MUN than unsupplemented cows. Milk urea nitrogen was influenced by $\mathrm{M} \times$ week and $\mathrm{S}$ 
Table 7. Effect of dietary starch and monensin on milk fatty acid (FA) composition

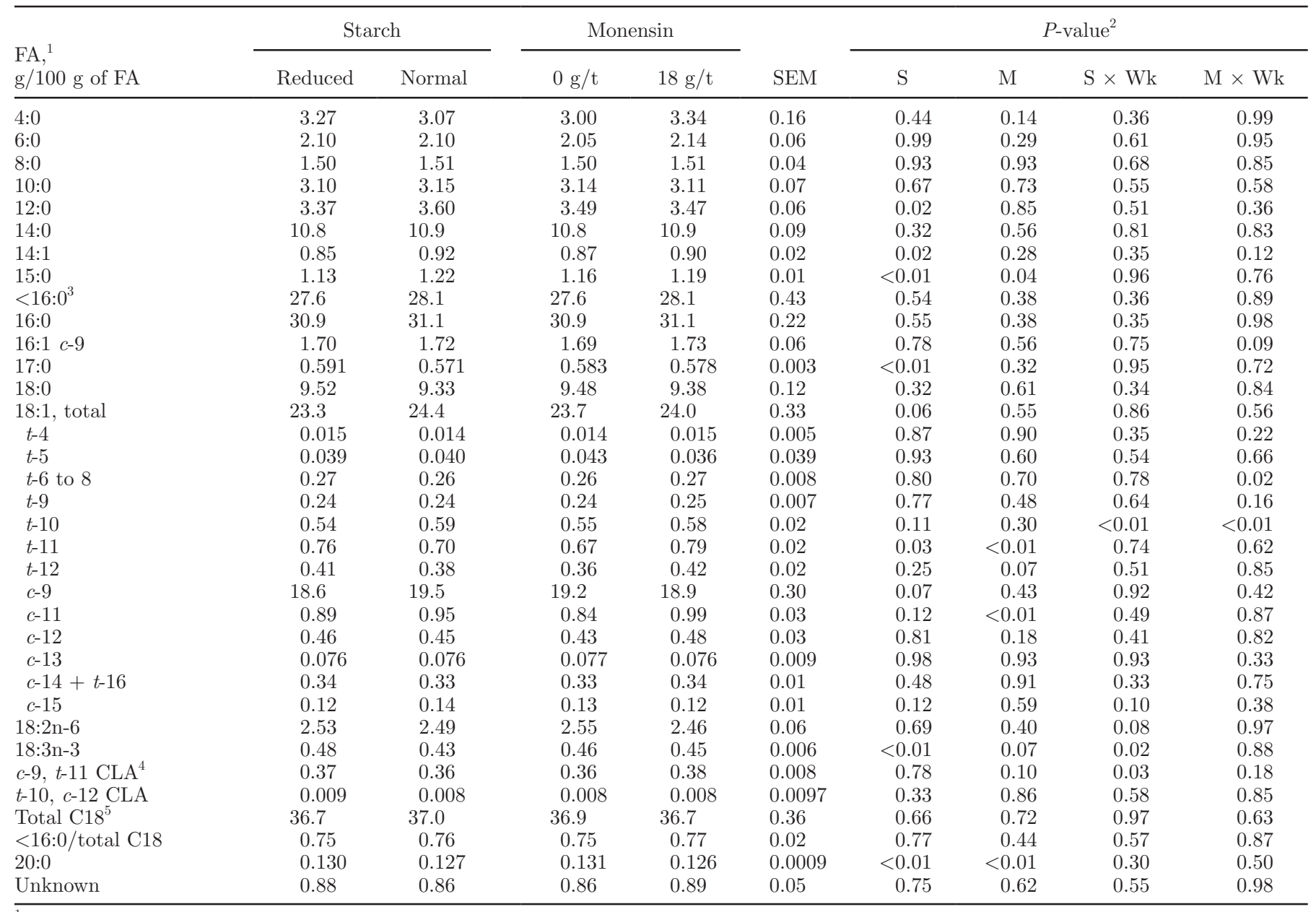

${ }^{1} c=$ cis; $t=$ trans.

${ }^{2} \mathrm{~S}=$ starch; $\mathrm{M}=$ monensin.

${ }^{3}<16: 0=$ sum of FA with 4 to 15 carbons.

${ }^{4}$ Conjugated linoleic acid.

${ }^{5}$ Total $\mathrm{C} 18=$ sum of FA with 18 carbons.

$\times$ week interactions $(P<0.01)$. During the first $3 \mathrm{wk}$ on treatment, MUN was greater $(P<0.05)$ for $\mathrm{M}$ and RS compared with $\mathrm{C}$ and NS, respectively. Increased MUN during the first weeks of feeding an RS diet is consistent with work by Gencoglu et al. (2010) and Ferraretto et al. (2011), where increases to about 18 to $20 \mathrm{mg} / \mathrm{dL}$ in the first week of treatment were reported. The greater MUN concentration for RS is likely related to less available carbohydrate for rumen microbial protein synthesis (Oba and Allen, 2003) and lower utilization of rumen ammonia for microbial protein (Hristov et al., 2005). Body weight, BW change, BCS, and BCS change were unaffected by $\mathrm{S}$ or $\mathrm{M}$ or their interaction $(P>0.10)$. Estimated diet energy content (Tables 5 and 6$)$ was unaffected by $\mathrm{S}(P=0.69)$ but significantly affected by $\mathrm{M}$, with M-supplemented diets having greater energy content than $\mathrm{C}(P<0.01)$. Gencoglu et al. (2010) also did not find a significant effect of starch when feeding RS and NS diets using soyhulls to replace corn grain. The $\mathrm{S} \times \mathrm{M}$ interaction approached a tendency $(P=0.11)$ for estimated diet energy content, with $\mathrm{M}$ supplementation having a numerically greater effect on NS than on RS diets, which is a similar interaction effect found for AMFE discussed previously. The $\mathrm{S} \times \mathrm{M}$ interaction may be due to $\mathrm{M}$ having greater effects on NS diets, which have increased starch digested ruminally and propionate produced than RS diets.

Main effects of $\mathrm{S}$ and $\mathrm{M}$ on milk FA composition and yield are presented in Tables 7 and 8. Overall, the effects of $\mathrm{S}$ and $\mathrm{M}$ on milk FA composition were minimal compared with studies in which supplemental oils were fed (AlZahal et al., 2008; He et al., 2012). We 
Table 8. Effect of the main effects of dietary starch and monensin on milk fatty acid (FA) yield ${ }^{1}$

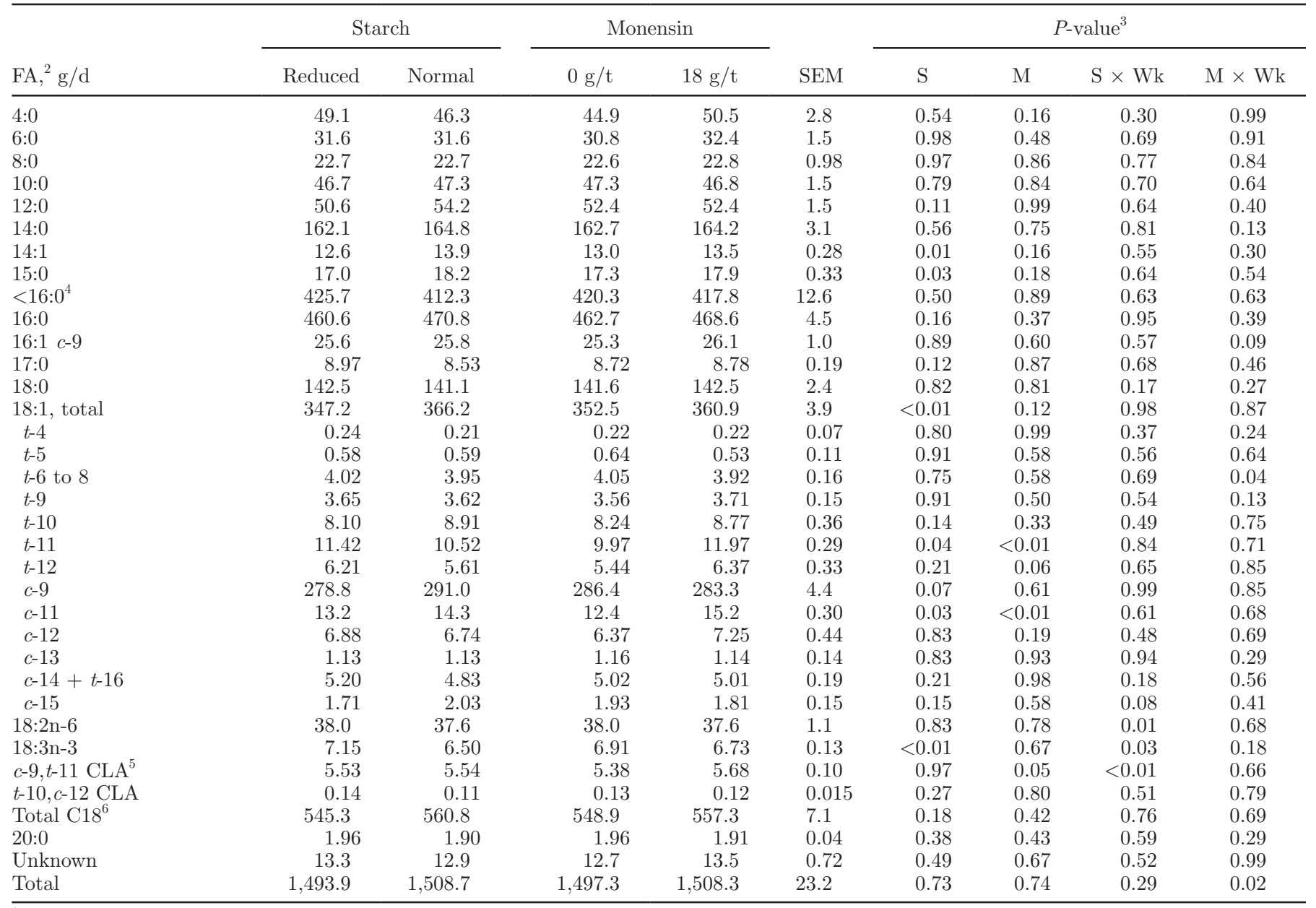

${ }^{1}$ FA yields were calculated based on the estimation that total FA account for 93.3\% of milk total lipids (Glasser et al., 2007).

${ }^{2} c=$ cis; $t=$ trans.

${ }^{3} \mathrm{~S}=$ starch; $\mathrm{M}=$ monensin.

${ }^{4}<16: 0=$ sum of FA with 4 to 15 carbons.

${ }^{5}$ Conjugated linoleic acid.

${ }^{6}$ Total $\mathrm{C} 18=$ sum of FA with 18 carbons.

observed small yet statistically significant effects of $\mathrm{S}$ and $\mathrm{M}$ on $\mathrm{FA}$ composition and yield. An interaction of $\mathrm{S} \times \mathrm{M} \times$ time (Figure $4 ; P<0.01$ ) was found for the concentration of milk $\mathrm{C} 18: 1$ trans-10, with cows fed NS-M having greater concentrations than the other treatments during wk 2, cows fed NS-M or NS-C having greater concentrations than RS-C during wk 4, and no differences among treatments during wk 8 and 12 on treatment. No S or M effects were observed for yield of C18:1 trans-10 $(P>0.10)$. The FA C18:1 trans-10 has also been previously associated with milk fat depression (Shingfield et al., 2009). Monensin supplementation has previously been shown to increase C18:1 trans-10 concentrations and yield (He et al., 2012). Starch content and $\mathrm{M}$ supplementation did not affect $(P>0.10)$ milk concentration of $\mathrm{C} 18: 2$ trans-10,cis-12, which is a precursor to $\mathrm{C} 18: 1$ trans-10 during altered rumen biohydrogenation (Griinari and Bauman, 1999). In addition, milk concentrations and yields of C18:1 trans- 11 were greater $(P<0.05)$ for cows fed RS compared with NS or M compared with $\mathrm{C}$. The shift in formation from C18:1 trans-11 to C18:1 trans-10 when feeding the NS diet indicates altered rumen metabolism and pathways of biohydrogenation (Bauman and Griinari, 2001) that cause milk fat depression; however, the current study did not reveal a decrease in milk fat percentage or yield for NS. The increase in C18:1 trans-11 concentration for cows fed M may indicate changes in rumen microbial population and inhibition of the final biohydrogenation step of this FA to C18:0 (Bauman and Griinari, 2001). 


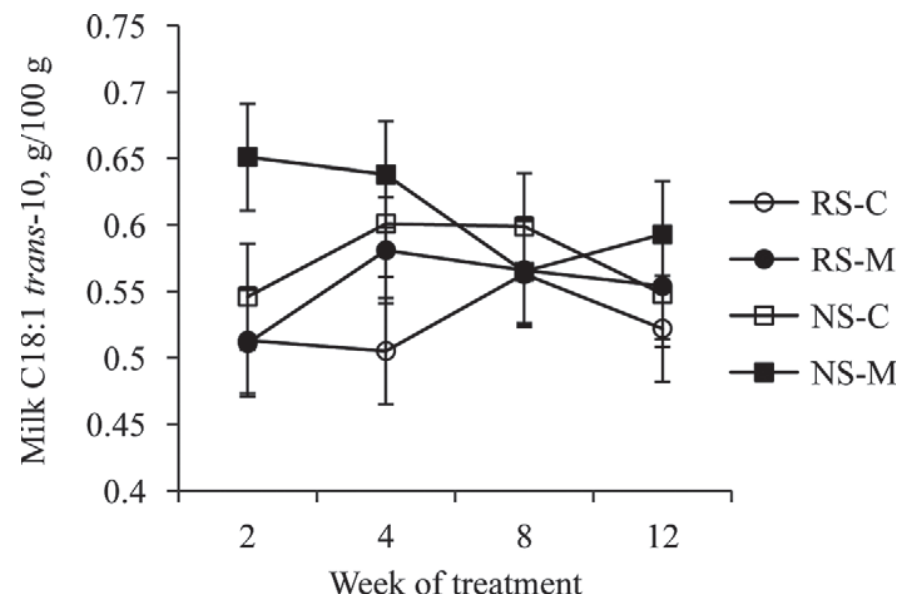

Figure 4. Covariate-adjusted means for milk C18:1 trans-10 fatty acid concentration of lactating dairy cows fed diets with and without monensin and 2 starch concentrations. RS-C = reduced starch diet without monensin; RS-M = reduced starch diet with monensin; NS-C $=$ normal starch diet without monensin; NS-M = normal starch diet with monensin. Starch $\times$ monensin, $P=0.08 ; \mathrm{SEM}=0.3$.

Feeding $\mathrm{M}$ has previously altered milk FA composition by decreasing saturated FA and increasing trans-C18:1 and C18:2 CLA (Sauer et al., 1998) and was attributed to decreased ruminal biohydrogenation.

Replacing starch with nonforage fiber from soybean hulls decreased $(P<0.05)$ milk FA concentrations of C12:0, C14:1, and C15:0, with no difference $(P>0.10)$ found for total short- and medium-chain milk FA (C $<16$ ). In addition, cows fed RS diets had increased concentrations and yields of C18:3n-3 $(P<0.01)$, and tended to have decreased concentrations of total C18:1 $(P=0.06)$ and $\mathrm{C} 18: 1$ cis-9 $(P=0.07)$ compared with cows fed NS. The yield of total C18:1 and C18:1 cis-11 were also decreased $(P<0.05)$ for cows fed RS compared with NS. The differences in C18:1 FA between RS and NS may be due to inherent differences in composition of the diets. The NS grain mix contained $6.3 \%$ ether extract (DM basis) compared with $5.3 \%$ in the RS grain mix (see Table 3). The ether extract content of the NS grain mix may have increased the unsaturated FA content of the diet and thus the concentration of total C18:1 FA in the rumen. When using distillers grain and soy hulls to replace DGSC and soybean meal, Ranathunga et al. (2010) observed no differences in milk fat and milk FA composition for cows fed diets containing 20 to $29 \%$ starch. The authors speculated that the cows maintained normal rumen function and that rumen biohydrogenation was not affected by the dietary differences in NDF, starch, or FA composition. Ipharraguerre et al. (2002) reported increased milk fat content and yield when substituting soybean hulls for DGSC. This change was explained as possibly resulting from the high polyunsaturated FA content of the oil in DGSC, which increased ruminal production of C18:2 trans-10, cis-12 FA; however, no milk FA analysis was reported in that study. In the current study, we did not observe an effect of $\mathrm{S}$ on milk fat content or C18:2 trans-10,cis-12. Overall, the effects of S and M on milk FA were minimal compared with studies that supplemented oils.

Total-tract starch digestibility was 1.3 percentage units greater $(P<0.01 ; 98.1$ vs. $96.8 \%)$ for RS than NS (data not shown). Gencoglu et al. (2010) observed a similar effect of $\mathrm{S}$, with total-tract starch digestibility being 2.3 percentage units greater for RS than for NS. Firkins (1997) explained the increase in starch digestibility of RS diets as being due to reduced negative associative effects of starch on ruminal fermentation. Dietary $\mathrm{M}$ inclusion did not affect $(P=0.26 ; 97.3$ and 97.5 for $\mathrm{M}$ and $\mathrm{C}$, respectively) total-tract starch digestibility.

\section{CONCLUSIONS}

Milk yield was reduced for cows fed the RS diet, but DMI, 3.5\% FCM, ECM, and SCM yields, and feed efficiencies were similar for RS compared with NS. Differences in dietary starch concentration or dietary inclusion of monensin had minimal effects on milk FA composition. In this study, RS diets were feasible for reducing corn inclusion in lactating cow diets. Inclusion of monensin at $18 \mathrm{~g} / \mathrm{t}$ of $\mathrm{DM}$ improved lactation performance, specifically actual and component-corrected milk feed efficiencies, on both RS and NS diets. We observed few significant interactions of starch and monensin, supporting the use of monensin in diets of both reduced and normal starch concentrations.

\section{ACKNOWLEDGMENTS}

The authors thank Elanco Animal Health (Greenfield, IN) for partial funding of this study and the Vita Plus Corporation (Madison, WI) for mixing of the experimental premixes. In addition, we thank Mike Peters, Sandy Trower, and the staff at the University of Wisconsin-Madison Blaine Dairy for animal care and management. The authors acknowledge Shane Fredin, Luiz Ferraretto, and fellow University of WisconsinMadison dairy science graduate students for assistance with sampling. The authors also thank Peter Crump of the University of Wisconsin CALS Computer Consulting Laboratory for assistance with statistical analysis of the data.

\section{REFERENCES}

Allen, M. S. 1997. Relationship between fermentation acid production in the rumen and the requirement for physically effective fiber. J. Dairy Sci. 80:1447-1462. 
Allen, M. S., B. J. Bradford, and K. J. Harvatine. 2005. The cow as a model to study food intake regulation. Annu. Rev. Nutr. 25:523-547.

Allen, M. S., B. J. Bradford, and M. Oba. 2009. The hepatic oxidation theory of the control of feed intake and its application to ruminants. J. Anim. Sci. 87:3317-3334.

AlZahal, O., N. E. Odongo, T. Mutsvangwa, M. M. Or-Rashid, T. F. Duffield, R. Bagg, P. Dick, G. Vessie, and B. W. McBride. 2008. Effects of monensin and dietary soybean oil on milk fat percentage and milk fatty acid profile in lactating dairy cows. J. Dairy Sci. 91:1166-1174.

AOAC International. 1995. Official Methods of Analysis. 16th ed. AOAC International, Arlington, VA.

Bach Knudsen, K. E. 1997. Carbohydrate and lignin contents of plant materials used in animal feeding. Anim. Feed Sci. Technol. 67:319-338.

Baker, S., and T. Herrman. 2002. Evaluating particle size. MF-2051. Kansas State Univ. Coop Ext. Serv., Manhattan.

Batajoo, K. K., and R. D. Shaver. 1994. Impact of nonfiber carbohydrate on intake, digestion, and milk production by dairy cows. J. Dairy Sci. 77:1580-1588.

Bauman, D. E., and J. M. Griinari. 2001. Regulation and nutritional manipulation of milk fat: Low-fat milk syndrome. Livest. Prod. Sci. 70:15-29.

Beckman, J. L., and W. P. Weiss. 2005. Nutrient digestibility of diets with different fiber to starch ratios when fed to lactating dairy cows. J. Dairy Sci. 88:1015-1023.

Broderick, G. A. 2004. Effect of low level monensin supplementation on the production of dairy cows fed alfalfa silage. J. Dairy Sci. $87: 359-368$.

Bucholtz, H. 2006. Feeding practices of high-producing herds; What can we learn? Pages 157-177 in Proc. Western Canadian Dairy Semin., Red Deer, Alberta, Canada. University of Alberta, Edmonton, AB, Canada.

Chouinard, P. Y., L. Corneau, D. M. Barbano, L. E. Metzger, and D. E. Bauman. 1999. Conjugated linoleic acids alter milk fatty acid composition and inhibit milk fat secretion in dairy cows. J. Nutr. 129:1579-1584.

Duffield, T., R. Bagg, D. Kelton, P. Dick, and J. Wilson. 2003. A field study of dietary interactions with monensin on milk fat percentage in lactating dairy cattle. J. Dairy Sci. 86:4161-4166.

Duffield, T. F., A. R. Rabiee, and I. J. Lean. 2008. A meta-analysis of the impact of monensin in lactating dairy cattle. Part 2. Production effects. J. Dairy Sci. 91:1347-1360.

Fellner, V., F. D. Sauer, and J. K. G. Kramer. 1997. Effect of nigericin, monensin, and tetronasin on biohydrogenation in continuous flowthrough ruminal fermentors. J. Dairy Sci. 80:921-928.

Ferraretto, L. F., and R. D. Shaver. 2012. Effect of corn shredlage on lactation performance and total tract starch digestibility by dairy cows. Prof. Anim. Sci. 28:639-647.

Ferraretto, L. F., R. D. Shaver, M. Espineira, H. Gencoglu, and S. J. Bertics. 2011. Influence of a reduced-starch diet with or without exogenous amylase on lactation performance by dairy cows. J. Dairy Sci. 94:1490-1499.

Firkins, J. L. 1997. Effects of feeding nonforage fiber sources on site of fiber digestion. J. Dairy Sci. 80:1426-1437.

Gencoglu, H., R. D. Shaver, W. Steinberg, J. Ensink, L. F. Ferraretto, S. J. Bertics, J. C. Lopes, and M. S. Akins. 2010. Effect of feeding a reduced-starch diet with or without amylase addition on lactation performance in dairy cows. J. Dairy Sci. 93:723-732.

Glasser, F., M. Doreau, A. Ferlay, and Y. Chilliard. 2007. Technical note: Estimation of milk fatty acid yield from milk fat data. J. Dairy Sci. 90:2302-2304.

Griinari, J. M., and D. E. Bauman. 1999. Biosynthesis of conjugated linoleic acid and its incorporation into meat and milk in ruminants. Pages 180-200 in Advances in Conjugated Linoleic Acid Research. M. P. Yurawecz, M. M. Mossoba, J. K. G. Kramer, M. W. Pariza, and G. J. Nelson, ed. AOCS Press, Champaign, IL.
He, M., K. L. Perfield, H. B. Green, and L. E. Armentano. 2012. Effect of dietary fat blend enriched in oleic or linoleic acid and monensin supplementation on dairy cattle performance, milk fatty acid profiles, and milk fat depression. J. Dairy Sci. 95:1447-1461.

Hristov, A. N., J. K. Ropp, K. L. Grandeen, S. Abedi, R. P. Etter, A. Melgar, and A. E. Foley. 2005. Effect of carbohydrate source on ammonia utilization in lactating dairy cows. J. Anim. Sci. 83:408-421.

Ipharraguerre, I. R., and J. H. Clark. 2003a. Soyhulls as an alternative feed for lactating dairy cows: A review. J. Dairy Sci. 86:10521073.

Ipharraguerre, I. R., and J. H. Clark. 2003b. Usefulness of ionophores for lactating dairy cows: A review. Anim. Feed Sci. Technol. 106:39-57.

Ipharraguerre, I. R., R. R. Ipharraguerre, and J. H. Clark. 2002. Performance of lactating dairy cows fed varying amounts of soyhulls as a replacement for corn grain. J. Dairy Sci. 85:2905-2912.

Kaiser, R., and R. D. Shaver. 2006. Benchmarking high producing herds. Pages 179-190 in Proc. Western Canadian Dairy Semin., Red Deer, Alberta, Canada. University of Alberta, Edmonton, AB, Canada.

Kononoff, P. J., A. J. Heinrichs, and D. R. Buckmaster. 2003. Modification of the Penn State forage and total mixed ration particle separator and the effects of moisture content on its measurements. J. Dairy Sci. 86:1858-1863.

Martinez, C. M., Y. H. Chung, V. A. Ishler, K. W. Bailey, and G. A. Varga. 2009. Effects of dietary forage level and monensin on lactation performance, digestibility, and fecal excretion of nutrients, and efficiency of feed nitrogen utilization of Holstein dairy cows. J. Dairy Sci. 92:3211-3221.

Mertens, D. R. 1987. Predicting intake and digestibility using mathematical models of ruminal function. J. Anim. Sci. 64:1548-1558.

NRC. 2001. Nutrient Requirements of Dairy Cattle. 7th rev. ed. Natl. Acad. Press, Washington, DC.

Oba, M., and M. S. Allen. 2003. Effects of diet fermentability on efficiency of microbial nitrogen production in lactating dairy cows. J. Dairy Sci. 86:195-207.

Ramanzin, M., L. Bailoni, S. Schiavon, and G. Bittante. 1997. Effect of monensin on milk production and efficiency of dairy cows fed two diets differing in forage and concentrate ratios. J. Dairy Sci. 80:1136-1142.

Ranathunga, S. D., K. F. Kalscheur, A. R. Hippen, and D. J. Schingoethe. 2010. Replacement of starch from corn with nonforage fiber from distillers grains and soyhulls in diets of lactating dairy cows. J. Dairy Sci. 93:1086-1097.

SAS Institute. 2004. SAS/STAT 9.1 User's Guide. Version 9.1 ed. SAS Institute Inc., Cary, NC.

Sauer, F. D., V. Fellner, R. Kinsman, J. K. Kramer, H. A. Jackson, A. J. Lee, and S. Chen. 1998. Methane output and lactation response in Holstein cattle with monensin or unsaturated fat added to the diet. J. Anim. Sci. 76:906-914.

Shaver, R. D. 2010. Improving starch digestibility in dairy cows: Opportunities with reduced- starch diets. Pages 90-93 in Proc. FourState Dairy Nutr. Mgmt. Conf., Dubuque, IA. Accessed Jun. 28, 2010. http://www.uwex.edu/ces/dairynutrition/documents/WASABook.pdf.

Shingfield, K. J., A. Sæbø, P. C. Sæbø, V. Toivonen, and J. M. Griinari. 2009. Effect of abomasal infusions of a mixture of octadecenoic acids on milk fat synthesis in lactating cows. J. Dairy Sci. 92:4317-4329.

Van Soest, P. J., J. B. Robertson, and B. A. Lewis. 1991. Methods for dietary fiber, neutral detergent fiber, and nonstarch polysaccharides in relation to animal nutrition. J. Dairy Sci. 74:3583-3597.

Wildman, E. E., G. M. Jones, P. E. Wagner, R. L. Boman, H. F. Troutt, and T. N. Lesch. 1982. A dairy cow body condition scoring system and its relationship to selected production characteristics. J. Dairy Sci. 65:495-501. 